\title{
An Examination of Causes of Delay in the Distribution of Estates in Ilorin and its Environs
}

\author{
Ismael Saka Ismael
}

\begin{abstract}
In the last two decades or thereabout, Area Courts and indeed other courts with jurisdiction to hear and determine Muslim matters in Ilorin have been inundated with cases involving distribution of estate of deceased Muslims who have died long time without having such estates distributed on time. Some of these cases dragged for a long time resulting into protracted litigation. The curiosity of the author to find out the cause(s) of these delays is the driving force for embarking on this research work. This paper is therefore, an indepth examination of the causes of delay in the distribution of estates of deceased Muslims of Ilorin specifically and the Muslims of Kwara State in general. Delay breeds litigation which most often becomes protracted. This paper is meant to serve as a clarion call to revert to application of pristine Islamic Law of Inheritance after identifying delay as a serious problem in the sphere of application of Islamic Law of Inheritance in the area under reference.
\end{abstract}

Keywords: Ilorin, Islamic Law, Estate Distribution, Inheritance

\section{Introduction}

Ilorin is both de facto and de jure a town inhabited by Muslims. ${ }^{1}$ The inhabitants of the town consist of the Yoruba, ${ }^{2}$ Hausa, Nupe, Baruba and Fulfulde speaking communities who form the major ethnic groups of Kwara State. Apart from these communities, there are other Yoruba and non-Yoruba speaking Muslims from the neighbouring Yoruba and non-Yoruba speaking States. The Muslim inhabitants of the town conduct their everyday life activities ${ }^{3}$ in accordance with the dictates, principles and doctrines of Islamic Law. ${ }^{4}$ Of all the activities of the Muslims of Ilorin, wedding, naming ceremonies and funeral rites receive a lot of prominence. The former two attract a lot of pomp and pageantry while the latter is observed with solemn soberness because it brings to an end the sojourn of man on this earth and marks the beginning of another chain of activities. ${ }^{5}$

The Muslims of Ilorin, while living, other Muslims elsewhere are naturally endowed with abundant insatiable instinct ${ }^{6}$ of acquisition of wealth ${ }^{7}$ which they exert some degree of absolute control ${ }^{8}$ over while they are alive. The Ilorin Muslim is a trustee ${ }^{9}$ of the wealth that he owns for the duration of his life. ${ }^{10}$ When his term of life expires, his trusteeship over his wealth and property expires too. No matter how much time the Muslim of Ilorin spend on this earth, one day, the end shall come by way of death. ${ }^{11}$ Since death is the ultimate end of man in his sojourn on this earth, it can be said to be a global phenomenon which no one prays for, yet a reality to all human beings because every human being shall have a taste of it. ${ }^{12}$ Upon the demise of a Muslim of Ilorin, he loses his right of ownership and absolute control of disposal of his wealth or estate because he cannot decide who takes what and cannot equally decide how it is to be disposed except what is permitted. ${ }^{13}$ It has to be distributed in accordance with the directive ${ }^{14}$ of the Real Absolute Owner-Allah $(S A W)$. So like any other place, in Ilorin, not until the inheritance is opened and the estate distributed, the heirs have no right whatever to the estate of their predecessor.

It is a general principle and practice of Islamic Law of Inheritance that a man is ceased of control over his assets as a result of death and as soon as the eight-day fidau prayer of a deceased Muslim is observed, his estate becomes due for distribution amongst his legitimate and legal heirs. ${ }^{15}$ This ought to be the practice and it is expected that any moment from this particular time, the estate of a deceased Muslim of Ilorin becomes due for distribution amongst his heirs in accordance with the Law of Intestate Succession in Islamic Law. However, in the last two decades or there about, it is observed that delaying distribution of estates has impacted and inhibited application of pristine Islamic Law in the area of estate distribution in accordance with Islamic Law (in Ilorin specifically and amongst the Muslims of Kwara State in general). This has brought about serious problem of inordinate delay and in some cases outright refusal to distribute estate amongst others with grave consequences. The socioeconomic and religio-legal consequences of delaying distribution of estate of a Muslim provides the enabling environment warranting undertaking a research into the causes of delay in the distribution of estates in Ilorin in particular and Kwara State in general. This research is therefore based on field work conducted in the Ilorin Emirate between 2000 and 2011. 


\section{Causes of Delay in Ilorin and its Environs}

A close study of some cases shows that variety of causes account for either ordinary ${ }^{16}$ or inordinate ${ }^{17}$ delay in the distribution of estate in Ilorin in particular and amongst the Muslims of Kwara State in general. These causes are:

\section{Fear of the Use of Supernatural Powers}

Delay in the distribution of estate of a deceased Muslim of Ilorin and among the Muslims of Kwara State is often caused by the customary belief, efficacy and general fear of the use of spiritual and supernatural power by the person in possession of the estate against the heirs in situations where the heirs are weak and of tender age. ${ }^{18}$ The fear of use of spiritual and supernatural power against them usually instills palpable fear in the minds of the heirs, thereby perpetually keeping them silent over the issue of distribution of estate. It will be recalled that many African Muslim Communities (Ilorin and indeed Kwara State inclusive) adopted Islam and Islamic ways of life and mixed it with traditional customs and practices especially in the preparation of charms and amulets ${ }^{19}$ which the people wear to protect themselves from evil misfortune, to bring prosperity and success against enemies and evil forces. This belief and practice is partly a result of the environment under which people live, where many things appear magical rather than logical because science has not affected the majority of the people's lives in any fundamental way. $^{20}$

\section{Lawyers' Attitude}

In Ilorin and among the Muslims of Kwara State, lawyers' attitude does not really constitute a major cause of delay in the distribution of estate because about ninety percent of estate distribution is done by the local Mallams, the Alfas i. e. Ulamas. Lawyers do not really get involved here. This is because generally, the Ilorin Muslim abhors court litigation and detests resorting to the courts by way of litigation to have estate distributed in deference to tradition. This is why it is a common adage amongst the people that "Aa kii ti kotu bo so re" meaning litigation breeds enmity rather than friendship. The Ilorin Muslim would rather prefer to suffer in silence by having the estate remain undistributed than resort to court litigation to effect distribution. ${ }^{21}$ This situation is slowly changing as a number of estate distributions are conducted through litigation, though the number is negligible.

However, in a few cases where estates distributed through court litigation, i.e., about ten per cent, lawyers' attitude comes to play in delaying distribution of estates in form of either seeking for adjournments on one reason or the other or in filing all sorts of motions (both ex-parte and on notice) or foot- dragging in cases that require obtaining letters of administration before effecting distribution. Letters of administration take months, in some extreme cases, years to obtain.

Apart from this, delayed distribution of estate in Ilorin in particular and amongst the Muslims of Kwara State in general, is also attributable to "unnecessary" appeals ${ }^{22}$ against decisions of trial courts arising from either the lawyer's failure or inability to properly analyze the issues and or law involved in the cases or for mere "development" of the law. The case of Madam Iyabo Imam v. Akanni Akibu \& 5 Ors, ${ }^{23}$ amongst others illustrates the point. In this case, the Plaintiff is consanguine sister of the first Defendant while 2nd to 6th Defendants are children of late germane brother (Alhaji Garuba Kaduna who predeceased his father) of the Plaintiff. The father of the Plaintiff, first Defendant and Plaintiff's late germane brother is late Shaba Mohammed Umaru who died on 21st January, 1981 while 2nd to 6th Defendants are grand children of late Shaba Mohammed Umaru from Garuba Kaduna.

The case arose as a result of agitation from 2 nd to 6 th Defendants for distribution of estate of late Garuba Kaduna, the germane brother of the Plaintiff. Upon full trial to determine ownership of the properties sought to constitute the estate to be distributed, the Upper Area Court 1, Ilorin in the last paragraph of its judgment in the case under consideration provides:

\begin{abstract}
The summary of the judgment therefore is that the Plaintiff is declared the owner of the property at Magajin Agbo Compound, Agaka, Ilorin and the two rooms at Opo-Malu. The properties at Magajin Gari, Idi-Ose, is to be shared according to Islamic Law of inheritance between the plaintiff and second to sixth (2nd - 6th) defendants while that at Magajin Gari, Surulere is to be administered in conformity with Sharia (Law of Succession) between the Plaintiff. Any dissatisfied party has a right of appeal to the High Court within 30 days (Emphasis mine).
\end{abstract}

In spite of the trial court stating in its judgment where appeal should go to, the defendants' counsel instead of appealing to the appropriate court, ${ }^{24}$ filed on appeal before Kwara State Shari'a Court of Appeal, Ilorin ${ }^{25}$ which was struck out ${ }^{26}$ on 30/3/06 on preliminary objection raised by Plaintiff/Respondent's Counsel on the ground that the Shari' a Court of Appeal lacks jurisdiction to entertain the suit. The suit was subsequently transferred ${ }^{27}$ from Shari' a Court of Appeal to the State High Court in its appellate jurisdiction. ${ }^{28}$ On the hear- 
ing date, 23/01/2007, the Appellants, realizing the futility of the appeal, withdrew ${ }^{29}$ it. The withdrawal of the appeal and its striking out by the State High Court (in its appellate session) provided the enabling environment for the Plaintiff/Respondent to have part of the property adjudged subject to inheritance in accordance with Shari'a be distributed in Madam Iyabo Imam v. Mrs Tinuke Akibu. ${ }^{30}$ The Defendant in this case is the eldest child of Akanni Akibu, the 1st Defendant in the withdrawn case. She was sued because by the time the case was eventually withdrawn from the High Court, Akanni Akibu had already died. The share meant for Akanni Akibu was distributed amongst his heirs because Garba Kaduna predeceased Shaba Mohammed Umaru, grandfather of 2nd to 6th Defendants.

A close study of the cases here will reveal that the attitude of lawyer(s) has contributed greatly to delaying the distribution of the estate which would have been carried out in 2005 instead of 2007, a delay of about two years or thereabout due to problem(s) associated with lawyers (earlier highlighted above) in the few cases that are resolved through litigation.

The Appellants' counsel's attitude in Alhaji Saka Opobiyi v. Layiwola Muniru ${ }^{31}$ also buttresses the assertion that the attitude of lawyers constitutes one of the major causes of delay in the distribution of estates in the very few cases of inheritance that are determined by means of court litigation in Ilorin and Kwara State in general. In this case, the Court of Appeal, Ilorin Division, on 11th July 2002 delivered its judgment which was not palatable to the Appellants. The Appellants' counsel appealed to the Supreme Court of Nigeria in Abuja vide Notice and Grounds of Appeal dated and filed on 31st July 2002. Rather than pursue the appeal in Abuja to a logical conclusion, he decided to indulge in judicial window shopping by dissipating his energy on proceedings for stay of execution of judgment of 11th July, 2002 and interlocutory injunction which was filed on 31st July 2002 and concluded on 13th January $2004{ }^{32}$ The Court of Appeal, Ilorin Division, however refused to grant stay of execution of judgment but restrained and ordered both parties to maintain status quo.

In spite of the restraining order of the Court of Appeal, instead of pursuing the substantive suit, the Appellants' counsel initiated contempt proceedings against the Respondent, Layiwola Muniru, on 4th October 2004. This proceeding was dismissed for lack of merit on 6th February 2006. In its ruling of dismissal, the Court of Appeal, Ilorin Division, alluded to the assertion that lawyers' attitude constitutes a cause of delay in distribution of estate as the court held inter alia that:

...In fact there is no clear evidence that this court's Order of 13th January, 2004 was in any way flouted by the Respondents. Both counsel are to be blamed for unnecessary delaying the hearing of this matter to its logical conclusion. It is clearly from the record that the land in dispute, which is the subject matter of inheritance, was in fact, unscathed and untouched... ${ }^{33}$ (Emphasis mine).

After failure of all these unnecessary judicial voyage of discoveries, the Appellants' counsel by a motion (at the Supreme Court of Nigeria) dated 27th March 2008 heard and granted on 10th December 2008, decided to pursue the substantive suit. ${ }^{34}$ From the above analysis, it is vividly clear that attitude of counsel has caused a delay of about seven years (from 11th July 2002 to 5th January 2009) in the course of having the case being decided finally.

\section{Judges' Attitude}

Judges of Courts ${ }^{35}$ constitute one of the three ${ }^{36}$ classes of distributors of estates of deceased Muslims in Ilorin in particular and Kwara State in general. The attitude of some of these judges contributes to the delay associated with cases of inheritance that are determined through court litigations. It should be borne in mind that cases of estate distribution in accordance with Islamic Law decided through litigation are very few in Ilorin due to reasons advanced earlier in this paper.

For the purpose of discussing this class of distributors, i.e., the judges of courts, emphasis would be placed on the Area Courts because they are the courts of first instance while the others ${ }^{37}$ perform supervisory ${ }^{38}$ and appellate $^{39}$ functions as the case may be. In reality, within this class of estate distributors, the Area Courts, being courts of first instance, are the ones involved in actual and physical distribution of estates of deceased Ilorin Muslims whose relations have to resort to them for resolution where distribution by either of the other two classes of distributors would not achieve the result due to one problem or the other. For the purpose of illustrating this assertion is the case of Madam Iyabo Imam v. Mrs. Tinuke Akibu ${ }^{40}$ which is a case involving distribution of estate of late Shaba Mohammed Umoru which arose from the determination of property owned by the deceased (late Shaba Mohammed Umoru) and late Garuba Kaduna being subject to inheritance in accordance with Islamic Law in Madam Iyabo Imam $v$. Mr. Akanni Akibu \& 5 Ors. $^{41}$ 
The Area Courts used to be known and called Provincial Courts (Native Courts) during the colonial era. They were established then by Warrant under the hand of a Provincial Commissioner within his province as he shall think fit, ${ }^{42}$ subject to confirmation by the Minister. Today, in Kwara State, these courts are no longer called Native Courts but Area Courts and they are established by Warrants under the hand of the Chief Judge who may establish them as he shall think fit. ${ }^{43}$ The Courts, during colonial era, had "alkali", a person learned in Moslem Law as the alkali ${ }^{44}$ and they hear and determine civil matters amongst others which involve questions of Moslem personal Law. ${ }^{45}$ The alkali of that time, though they were not trained in the modern conventional legal education, ${ }^{46}$ were however, very versed and experienced in Islamic Law and procedure. They attended the traditional Makarantar Allo, Makarantar ilimi and the Kano Law School. Today, in Kwara State, about ninety percent of judges in the various Area Courts (Upper Area Courts inclusive) possess a degree in either Islamic Law or combined degree of Common and Islamic Laws ${ }^{47}$ while majority of them, in addition to possessing a degree in Islamic Law or Common and Islamic Laws, are also qualified legal practitioners ${ }^{48}$ by the definition of Legal Practitioners Act. $^{49}$

At this juncture, it is pertinent to state that notwithstanding the volume of cases before the trial courts, the attitude of the judges, especially those of the Area Courts, including Upper Area Courts, and some other factors ${ }^{50}$ contribute immensely to congestion of cases in these courts which account for the snail like pace of administration of justice in Ilorin in particular and Kwara State in general. The result of this is delay in concluding most of these cases which include the ones on estate distribution. The point the researcher is making here is most likely to be appreciated by using the case of Abdullahi Ibrahim v. Baba Tapa \& Ibrahim Koto $^{51}$ as illustration. In this case, the Grand Kadi of Kwara State Shari' a Court of Appeal, Ilorin, in a ruling written and delivered by his Lordship stated that:

...we want to take judicial notice of the fact that we had cause in 2004 to listen to the same complaint from the same party on the same matter and in the same manner. We must confess that we are worried, sad and concerned that this suit, on the succession of two rooms, filed since 16th March, 2001 remains unresolved till today. It is unfortunate to say the least. In the Upper Area Court 1, it suffered seven adjournments before it was transferred to Upper Area Court II, Ilorin in December, 2003. Due to similar neglect the applicant filed a motion KWS/SCA/CV/M/IL/ 14/2003 decided on 9th June, 2004 before us... ${ }^{52}$ (Emphasis mine)

Based on the researcher's experience in legal practice in these courts, corruption, a cancer worm not peculiar to the judicial arm of the government is the most probable cause of the judge's attitude and behaviour in this case. Public institutions in Nigeria today have lost their values due to corruption. The judiciary as a whole is no exception as it is replete with corruption. Many judges have conspired through their attitude and corrupt tendencies to bring the profession into disrepute. They have eroded the last hope of the common man. ${ }^{53}$ Of recent, the Chief Justice of Nigeria was accused by the President of Court of Appeal of trying to interfere in a diabolic manner with the outcome of the Sokoto State Gubernatorial election tribunal decision. ${ }^{54}$ As if that was not bad enough, it has also been reported that there has been a scam involving six billion Naira in the National Judicial Institute of which the Chief Justice of Nigeria is the Chairman. ${ }^{55}$ Also, some years ago, the Administrator of the Institute, Justice Oyeyipo, a retired Chief Judge of Kwara State, was relieved of that position for financial impropriety. The incumbent Administrator of the Institute, Justice Umaru Eri, a retired Chief Judge of Kogi State who took over from Justice Oyeyipo is said to be at the centre of the alleged scam. ${ }^{56}$ If these high ranking judicial personalities could stoop so low as to get themselves enmeshed in these unethical behaviours, what else do we expect from an Area Court judge?. Nemesis would certainly catch up with them one day as it did with judge Abdullahi who was charged for corruption in C. O.P. v. Alhaji Ibrahim Abdullahi ${ }^{57}$ before an Ilorin Chief Magistrate Court in Kwara State.

By the First Information Report (F.I.R.) in the case under reference, the accused was the presiding judge of Upper Area Court, Ganmo. He was standing trial for the offence of "public service in judicial proceeding acting contrary to law and public servant taking gratification in respect of Judicial Act contrary to Sections 125 and 115(2) of Penal Code". It was alleged against the accused that:

On 10th March, 2011, at about 1300hrs, on the strength of a letter of complaint with Ref. No. C.42B/Vol. IV/711 dated 3rd March, 2011 received from the Judiciary, Chief Registrar's Chamber, Ilorin signed by S. T. Abdulkadir (Mrs) addressed to the Commissioner of Police and endorsed to this department for discreet investigation wherein it was reported that on 27th January, 2011 four suspects namely (1) Yusuf Abayomi (2) Busari Shehu (3) Usman Salami and (4) Olabode Olabi- 
si all of various addresses in Ilorin township were arraigned in Court on First Information Report before Upper Area Court Ganmo being presided over by you Hon. Alhaji Ibrahim Abdullahi and Hon. Ganiyu Mustapha for various Traffic Offences by the Nigerian Police, 'A' Division Ilorin. It was further reported that contrary to the regular judicial process, you Hon. Ibrahim Abdullahi, a Public Servant in judicial proceeding, acted contrary to the laid down rules, tried the suspects summarily convicted them without following the due judicial process, after which you allowed the convicts to go home to source for the fines imposed on them till on the 28th January, 2011 when they came back to the court to pay the fines. It is further alleged that contrary to the laid down laws, you personally collected the said fine and issued receipts to the convicts which did not reflect the actual amount of fines imposed on them by your court. Discreet Police Investigation revealed that you a Public Servant in judicial proceeding acted contrary to law and equally took gratification in respect of your judicial Act.

It is sad to state that this case got terminated through filing of a Nolle and the Area Court Judge was removed as one and made head of Court Interpreters. It is however not all the judges that are bad but the very few bad eggs amongst them are dragging the name of the judiciary to the mud. As observed earlier, the issue of corruption is not limited or peculiar to the judiciary; it is a cancerous worm afflicting all public institutions in Nigeria.

\section{Ulamas' Role in Society}

In Ilorin and Kwara State in general, the Ulama are commonly known, referred to and called Alfas or Afas. From religious perspective, their role in the society is very vital and multi-dimensional to the extent that this cannot be over-emphasized. A few of their roles and responsibilities are leading prayers (Imam), public preaching on Islam, Islamic rites and Islamic religious way of life, conducting Islamic naming ceremonies, conducting Islamic Nikkah, conducting Janaza prayer and distribution of estates of deceased Muslims in accordance with Islamic Law amongst others. They are people well versed in Arabic, Islamic Studies, Islamic Law and a host of other fields of Islamic knowledge. The Alfas/Afas constitute the major class of estate distributors in Ilorin and Kwara State as a whole because majority of estate distribution is done through this means than through the courts as pointed out earlier.

Before delving into the role of Alfas/Afas, i. e., Ulamas (Local Mallams) with regard to estate distribution in Ilorin and Kwara State, the researcher wishes to cate- gorically state that Ilorin ${ }^{58}$ is a place of men of learning and knowledge in Islam and Islamic Education even before $^{59}$ and after $^{60}$ the coming of Sheikh Alimi ${ }^{61}$ and his Jama'a and subsequent settlement in Ilorin. From time immemorial to date, Ilorin has been blessed with men of great learning in a number of branches of Islam and Islamic Education. Majority of these erudite and distinguished scholars of repute in Islam and Islamic Education are of blessed memory ${ }^{62}$ while some others are still alive. ${ }^{63}$

These erudite Muslim scholars of Ilorin (past and present) have the basic general knowledge of almost all the spheres of Islam and Islamic Education (including law) to qualify to be called and referred to as "Alfas" or "Afas" and to hold position of office of an "Imam" in some cases and in other cases, qualified to be even judges of an Islamic Court. In addition to having the basic knowledge of the various fields of Islam and Islamic Education, each and every one of them has his area of specialization such as:

Tafsirul Qur'an, knowledge of the interpretation and application of the text of Qur'an, its literature such as its diction, phraseology, Science of Hadith, 'Ilmul Fara'id, Succession law, Tarikh, History of Islam and Muslim personalities, Sufism; Theory and Practice of mysticism, Mantiq logic in Islamic Studies, Da'wah, Science of propagation of the Faith, Tawhid, Science of the concept of the unity of Allah and many other branches of Islamic Studies known as Funun. ${ }^{64}$

Each of these erudite and prominent Islamic scholars of Ilorin (past and present) are reputedly known and associated with possessing in depth knowledge and skills in one or more areas of the aforementioned areas of specialization. There is however, none of these scholars (past or present) prominently and reputedly acclaimed to have specialized in the knowledge and skill of distribution of estate or associated with the field and skill of 'Ilmul-Fara'id. Even if there is, such scholar(s) has/have not been widely acclaimed in Ilorin in particular and Kwara State in general as it is with respect to other fields of specialization such as Sufism, ${ }^{65} \mathrm{Da}$ 'wah, general Arabic and Islamic scholarship $^{66}$ to mention but a few areas.

From the above analysis, it is presumed and it ought to be that when it comes to the areas of specialization, it is the expert in the relevant field that takes the stage to handle the issue(s) at stake as the case may be. This is because each area of specialization has developed its jurisprudential science to solve any given knot, even 
though they all have common primary sources, ${ }^{67}$ i.e., the Glorious Qur'an and Hadith/Sunnah.

These days it is not uncommon in Ilorin and amongst the Muslims of Kwara State, to find Alfas who are not versed in the knowledge, skill and art of estate distribution indulging in estate distribution when called upon to do so by heirs. ${ }^{68}$ The researcher, in the course of this research and as an active participant in the distribution of estate of XYZ in Share, ${ }^{69}$ a suburb of Ilorin, a resident Alfa who was an observer in the distribution of the estate in question, informed me after the distribution exercise that, that was his first experience in life as an Alfa to witness actual physical distribution of estate even though he had been involved in the teaching of students of Madrasat Arabic and Islamic Knowledge (including theoretical rules of Islamic Law of Inheritance) for more than ten years or thereabout.

Similarly, during the course of this research, the researcher's experience, especially in a particular case ${ }^{70}$ of estate distribution by some Alfas confirms that some Alfas who are not well versed in the knowledge of Islamic Law of Inheritance, skill and art of distribution indulge in estate distribution and find it difficult to turn down invitation to distribute estate. ${ }^{71}$ The particular case in question involved the distribution of ZYX estate. Inventory of the properties were taken as well as the list of the entitled heirs. Amongst the properties are two real properties. One being a modern building situated in commercial area of Ilorin while the other is made of mud walls situated in the traditional Ilorin setup. By design and location, the two buildings do not have the same monetary and or commercial value. Without ascribing value to them, the Alfas went ahead to allocate the building with less commercial value to particular heirs and the other to other heirs. This singular act of the Alfas somehow infuriated the heirs because they are from different mothers and the heirs halted, ${ }^{72}$ further distribution of the estate. The distribution could not be carried out to a logical conclusion by the Alfas because of their in experience and lack of possession of the art and skills of estate distribution. The Alfas, though, did not leave without taking honorarium for a service not rendered.

Unlike the past great Islamic scholars of Ilorin, today the bulk of those within the class of Alfas of Ilorin in particular and Kwara State in general, are people who do not go beyond the Idadiyyah ${ }^{73}$ Schools yet they claim to be Islamic Scholars whereas in reality, their knowledge of Islam itself is shallow, bearing in mind the downward trend of knowledge (both mundane and religious) generally. ${ }^{74}$ This, coupled with the fact that 'ilm ul-Fara'id is acclaimed to be one of the fields of knowledge that will fade away towards the end of the world, ${ }^{75}$ contribute probably to the dearth of scholars versed in the knowledge, skill and art of distribution of estate in accordance with Islamic Law. There is no doubt that the field of Islamic Law of Inheritance is very technical and can only be handled by experts ${ }^{76}$ only but regrettably today many self proclaimed $A l$ fas/Afas in Ilorin and indeed Kwara State dabble into it. $^{77}$

Discussion on the role of Alfas / Afas in the society with regards to delay in the distribution of estate in Ilorin and Kwara State in general would not be complete without reference to the fact that they fail (by omission or commission) to emphasize the importance of early distribution of estate during the usual third, fifth or eighth day (as the case may be) fidau prayer of the deceased Muslim. ${ }^{78}$ In almost all fidau prayers, Alfas / Afas do not or hardly make reference to this. What most of them do is to offer prayers for the repose of the soul of the deceased Muslim and concentrate so much on matters that would enhance their personal gains in form of monetary income. ${ }^{79}$ The researcher is not totally opposed to this since they do not have regular and consistent income nor other means of livelihood other than this service which is more of gratuitous community / religious service. They are however enjoined to always devout some time to stress the importance and the need for early distribution of estate of a deceased Muslim.

\section{Ignorance of the Law}

The researcher's interaction with some heirs (who plead to be made anonymous) during the course of this research work shows that lack of knowledge of Islamic Law of Inheritance and the nature of inheritance right in Islam on the part of some or all the heirs, in some cases, is responsible for delay in the distribution of estate amongst the Muslim communities of Kwara State. Majority of heirs interacted with do not realize that there is need for quick and timely distribution of estate. They do not see time as having any essence in distributing the estate of a deceased Muslim.

At times, ignorance is not limited to the law relating to the rules and principles of Islamic Law of Inheritance but also extends to the law relating to the legal system in respect of where, how and what method to adopt in seeking redress. The case of one princess Bilikisu Gambari illustrates this point. The princess, though educated, by a letter dated 19th August, 2007 to the Grand Kadi, Kwara State Sharia Court of Appeal, Ilorin inviting him to distribute the estate of her late father 
in their quasi-judicial function. The Grand Kadi declined the invitation because the invitation letter was signed by her alone. She was directed to get the other heirs to sign the letter. When she could not get other heirs to sign the letter, she got disenchanted. ${ }^{80}$ The problem here is that she could not differentiate between the appellate judicial function of the Kadis of the Kwara State Sharia Court of Appeal, Ilorin from their quasi-judicial function. They do not have original jurisdiction to hear and determine inheritance matters. What she ought to have done is to file a suit for distribution of estate at any Upper Area Court or any Area Court Grade 1 in Ilorin and it would go to the Shariah Court of Appeal on appeal where she is not satisfied with the distribution done at the court of first instance. Instead of doing this, she took the wrong step because of her ignorance of the law. From her action, she had wanted a court distribution and not a distribution through arbitration (sulh).

\section{Laissez-Faire Attitude}

Experience arising from the researcher's number of years ${ }^{81}$ in legal practice in cases involving inheritance in accordance with Islamic Law in Ilorin in particular and Kwara State in general, shows that "I don't care" attitude of heirs accounts for delay in the distribution of estates of deceased Muslims in the area under reference. This attitude stems from lack of zeal and courage amongst any of the heirs or even a non-heir to initiate the move to have the estate distributed. Absence of zeal and courage at times results from economic self sufficiency and or poverty. The combined effect of all these is that they provide enabling atmosphere for delay of distribution of estate to thrive.

\section{Economic Self-Sufficiency/Poverty}

Economic status of the heirs, in some cases, constitutes a cause of delay in the distribution of estate of a deceased Muslim of Ilorin and amongst the Muslims of other communities of Kwara State. By economic status is meant the economic buoyancy or otherwise of the heirs. Thus where the heirs of a deceased Muslim are economically buoyant, they may not bother to address their minds, for a very long time, to the issue of distribution of estate. Likewise, where majority of the heirs are economically self-sufficient and others are not and the estate is in the hand(s) of those who are economically buoyant, the heirs who are poor or weak, most especially on the part of the female heirs, ${ }^{82}$ would find it a bit difficult to initiate estate distribution, especially if the heirs are from a polygynous family.
The estate of one late Alhaji Abdullahi illustrates this point. The deceased was survived by both male and female children, wives and a mini-housing estate of six numbers of three-bedroom flats at Oke-Agodi Area of Ilorin amongst other assets. The flats in question were occupied by tenants who were paying just two hundred ( $\$ 200.00)$ Naira per flat per month prior to and after the death of the deceased. After the death of the deceased, the tenants were instructed by the heirs to pay rent to some old women including the widows of the deceased as a kind of up-keep allowance. For many years, the tenants were in default by owing accumulated rent running to years. The situation remained like that until one of the heirs (Musa Abdullahi) in 2001 volunteered and instructed the Law Firm of the researcher to commence action against all the tenants and eject all of them. ${ }^{83}$ Upon conclusion of the cases and realizing the economic value of each flat, ${ }^{84}$ the other heirs who had never shown any interest and were never willing to spend their own resources (if at all they have any) on the estate started agitating for distribution. Though, the flats were eventually distributed but without the self-less and volunteer efforts of the researcher's client, the asset in question would have probably remained undistributed till today.

\section{Large Estate Involving Shares of Floated Com- panies Within and Outside Nigeria}

Large estates involving shares of floated companies both within and outside Nigeria do constitute a cause of delay in the distribution of estates of deceased Muslims. This is due to the fact that ordinarily, where the estate of a deceased Muslim is large, there is no doubt that it will take some time to have the inventory taken and get the assets verified and where such estate involves shares of floated companies within and or outside the country, it will certainly take more time for the inventory to be taken and verified. Therefore, since these processes would have to be done before distribution takes place, this process would surely take a chunk of time and cause some kind of delay in the distribution of such estates.

Though, either as a researcher or as a private legal practitioner, in the course of this research work and within the area of study, the researcher did not come across any estate involving distribution of large estate involving shares of floated companies either within and or outside this country. It is however, not improbable and or not impossible that such estate exists or has existed in Ilorin in particular and Kwara State in general. The estate closest to what is being discussed here and found in the course of this research work is the estate 
of late Alhaji Adebayo Busari Alaya ${ }^{85}$ who died sometime in 2004 or thereabout. The real properties alone in the estate under reference were classified into $\mathrm{A}-\mathrm{F}$.

Properties in classification " $A$ " consisted of five rooms and five room and parlours, i. e., A1-A10 at Ero-Omo, Offa Garage Area in Ilorin while properties in classification "B" consisted of six flats, i. e. B1-B6 at opposite Afro-Works, off Offa Garage Road, Ilorin. Within "C" classification are properties consisting of twenty shops, six numbers of 4-bedroom bungalows, nine numbers of 3-bedroom bungalows and a 2-bedroom bungalow, all at Adewole Estate in Ilorin. The properties in class " $D$ " are buildings behind Petrol Stations (D1-D3). These are three numbers of room and parlour with separate kitchen and toilet behind Offa Garage Road Petrol Station, two numbers of rooms and parlour with kitchen behind Lagos Road Petrol Station, a parlour and three numbers of rooms with kitchen behind Lagos Road Petrol Station. Properties in classification "E", i. e., E1E6 consists of plots of undeveloped land. "E1" is 32 plots of land at New Yidi/Asa Dam Road in Ilorin while "E2" is 2 plots of land behind Olunlade Petrol Station in Ilorin. "E3' is 3 plots of land at Eiyenkorin Village while "E4" consists of 3 plots of land along Ballah Road. "E5" is 3 plots of land at EiyenkorinBallah Road and "E6" consists of 45 plots of land near Lagos Road Super Moon Petrol Station in Ilorin. The last class, class "F"( "F1-7") consists of Mercedez Benz Station Wagon car ("F1"), Toyota Corolla car ("F2"), Land Rover van ("F3"), Styre Lorry ("F4"), Bull dozer ("F5"), Low Bed with Volvo head ("F5") nad Kama 3 Gane ("F6") amongst others. ${ }^{86}$ In spite of the volume of the properties involved in this estate, its distribution did not experience much delay as it was concluded on 26th July, 2006 by the then Grand Kadi and his two other brother Kadis in their quasi-judicial functions (arbitration-sulh).

\section{Customs/Culture/Traditions}

Customs and traditions ${ }^{87}$ inhibit early distribution of estates of deceased Muslims in Ilorin in particular and Kwara State as a whole. The inhibition results from cultural belief that where either the father, uncle or a grown up son of the deceased controls everything left behind by the deceased, it is customarily and culturally a taboo for any of the heirs of the deceased to demand it from such head of the family, or to ask him to release the estate for distribution among the heirs. This is because the people believe that it is the duty and responsibility of the head of the family to maintain, manage and control the affairs of the dependants (in this case, including the dependants left behind by the deceased).
Therefore, to demand from such a person the immediate distribution of estate is more of an "abomination" and would amount to disrespect of the highest magnitude to an authority tantamount to undermining the authority of the head of the family. This practice seems to be a carry over of one of the practices of pre-Islamic period of the Arabs prior to the advent of Islam as exemplified in the case of estate of Aus bin Malik ${ }^{88}$ ( $R$. A.). These days, greed, love of materialism and desire to do justice leading to injustice is often the reasons why such persons hold on to estates of the deceased. ${ }^{89}$

Today, when heirs wait endlessly for the estate to get distributed due to operation of customs and tradition or any other cause and the distribution is not forthcoming, by the time their patience is over stretched, the heirs resort to court litigation as a necessary tool of effecting distribution but unfortunately, this tool, eventually and in most cases, turns out to be another cause of inordinate delay due to our snail like pace of justice administration. ${ }^{90}$ Most court litigations involving distribution of estate result from this endless waiting. Delay, whether ordinary or inordinate, can therefore be described as a keg of gun powder ready to explode at the appropriate time with very devastating effects and grave consequences. ${ }^{91}$

\section{Conclusion}

This paper has identified and analysed: Fear of the use of supernatural powers, lawyers' attitude, judges' attitude, Ulamas' role in the society, ignorance of the Law, Laissez-faire attitude, economic selfsufficiency/poverty, large estate involving shares of floated companies within and outside Nigeria; and Customs/Culture/Tradition as causes of deday in the distribution of estates of deceased Muslims in Ilorin in particular and Kwara State in general. 


\section{References and Endnotes}

${ }^{1}$ This fact is manifested in the number of mosques of various sizes and grades all over the nooks and crannies of Ilorin. If the number of these mosques are any thing to go by, then there is no doubt about the assertion above. Though, there are a handful of non-Muslims in Ilorin, their number is so negligible that they do not constitute a significant percentage of the people of the town.

2 The Yorubas of Kwara State can broadly be classified into four: the native Yorubas of Ilorin (who are found in Asa, Ilorin West, South and East, and some parts of Moro Local Government Areas), the Ibolos (who are found in Offa, Erin-Ile, Ira, Igosun), the Igbominas (who are found in Oro, Omu Aran, Ajase-Ipo, Oke-Ode, Igbaja and OroAgo) and the Ekitis (who are found in Ekiti Local Government Area of the State). The dialects and the culture/custom of these four Yoruba speaking communities of Kwara State vary from one speaking dialect to the other. Apart from these native Yoruba communities of Kwara State, there are also Yorubas of the neighbouring Yoruba speaking States of Oyo, Osun, Ondo, Ogun, Ekiti and Lagos. The dialects and culture/custom of these other Yoruba speaking communities of these States vary from those of the Yorubas of Kwara State.

${ }^{3}$ The most prominent activities are: wedding (Nikkah) ceremonies, Naming ceremonies and funeral rites and their incidental issues such as divorce (talaq), paternity, inheritance which are done in accordance with the principles, doctrines and procedures of Islamic Law.

${ }^{4}$ This probably accounts for provision of Area Courts, Upper Area Courts and Shar'iah Court of Appeal in the town and other parts of Kwara State to cater for disputes and controversies that may arise amongst the people, see Part II, Section 3, Area Court Law 1968 and Sections 275, 277, 278 \& 279 of the 1999 Constituiton of the Federal Republic of Nigeria, Cap. C23, Laws of Federation of Nigeria, 2007.

${ }^{5}$ The death of an Ilorin Muslim, like in any other part of the world, brings to the fore the issue of inheritance amongst the heirs of the estate left behind by the deceased.

${ }^{6}$ Man, whether Muslim, non-Muslim, humanist or atheist, white, Caucasian or negro, Nigerian or non-Nigerian anywhere in the Universe, has an insatiable instinct to acquire wealth. In buttressing this fact, the Prophet $(S A W)$ is reported to have said: "If people are given in accordance with their claims, some people may claim the property and blood-shedding of others..." to depict the tremendous insatiable instinct of possession and acquisition in human beings; see M.B. Sambo \& H. Mohammad, Islamic Religious Knowledge For WASC (Book 3), (Islamic Publications Bureau, Lagos, 1974), 116.

${ }^{7}$ The Muslims in Ilorin and of other parts of Kwara State, because of their Islamic and religious background are always mindful of the verses of Glorious Quar'an 2:198, 275 in their struggle to acquire wealth.
${ }^{8}$ It is trite principle of Islamic Law that a Muslim adult is free to dispose intra-vivo any quantity of his wealth to any body of his choice by way of either a gift or outright sale.

9 "...Unto Him belongeth what is in the heavens and whatsoever is in the earth..." see Qur'an $1: 2$.

${ }^{10}$ Islam and in fact Islamic Law does not frown at a Muslim (a Muslim of Ilorin inclusive) acquiring wealth, see Qur'an 4:32 where it provides: "for men is the benefit of what they earn." However, it frowns at acquiring unlawful wealth through lawful or unlawful means. Islamic Law therefore enjoins acquisition of lawful wealth through lawful means because every person shall account for how and what he or she acquired and how he or she spent his or her wealth, see Qur'an 2:198, Qur'an 2:275, Qur'an 2: 188, Qur'an 2:219, Qur'an 2:173, Qur'an $4: 32$.

${ }^{11}$ It is one of those pre-destined things which man has no control over. Equally, a person does not have control over when, where and how he or she will die.

12 "We have ordained death among you..." Qur'an 56: 60, the Prophet is reported to have said: "Be in this world as a stranger or as a wayfarer" to show that death is eminent, see M.O.A. Abdul, The Selected Traditions of ALNAWAWI (The Forty Traditions of AL-NAWAWI Arabic Text, Transliteration, Translation \& Commentary) (Book 4), (Lagos: Islamic Publications Bureau, 1974), 86-87.

${ }^{13}$ Allah by His volition permitted the Muslim to act by his discretion in one third of his estate in his possession. Abu Hurayrah reported that the Prophet (SAW) said: "God Almighty did a favour to you at the time of Your death through one third of your property so that your good deeds might increase" - Sunnan Ibn Madja, see AlAsqalani, Bulugh Al-Maram, (Part 2) (Riyadh: Dar-usSalam Publications, 1996/1416), Paragraph 822, 340-341. This discretion should however, not be exercised to the injury of the lawful heirs.

${ }^{14}$ Directives regarding the distribution of estate after the demise of the provisional owner are explicitly detaile in Qur'an 4:11-12.

${ }^{15}$ It is a common practice of the Muslims of Ilorin and indeed other Muslim Communities of Kwara State to announce to the public on the eight day fidau prayer for anybody indebted to the deceased or vice versa to the relations of the deceased for prompt settlement. This is to enable the relations to take inventory of the assets and liabilities left behind by the deceased. Whoever the deceased is owed and refuses to make the debt known to the relations of the deceased, such a creditor is presumed to have waived the debt for the deceased but this does not apply in a situation where the deceased is the creditor.

${ }^{16}$ Re -Estate of Alhaji Amusa Bashar, (Ilorin: Annual Report of Kwara State Sharia Court of Appeal, 1997). 159-165; Re-Esatate of Alhaji Mohammad Busari, Ilorin: Annual Report of Kwara State Sharia Court of Appeal, 1999), 140-147.

${ }^{17}$ Re-Estate of Alhaji Yahaya Gold, (Ilorin: Annual Report of Kwara State Sharia Court of Appeal, 2006), 308-320, 
Alhaji Alabi Opobiyi Vs. Alhaja Senabu Abebi Masingba (1982) C. A. 11 (Pt. I), 206.

${ }^{18}$ Some years ago, in the course of the author's private legal practice in Ilorin, a client related a nasty and pathetic story on how his spiritually powerful uncle sat on real property of his father. Nobody amongst the heirs of his father had the gut to challenge either the said uncle while alive or the children of the said uncle even ten years after the death of the uncle in question despite the fact that the heirs were then grown up and of age.

${ }^{19}$ M. H. Y. Kaniki, "Religious Conflict and Cultural Accommodation: The Impact of Islam on Some Aspects of African Societies", UTAFITI Journal of the Arts and Social Sciences, A Journal of the Faculty of Arts and Social Sciences, University of Dar es Salaam, Vol. 1, No. 1, (1976): 95.

${ }^{20}$ In the case of Muslims of Ilorin and the Muslims of Kwara State, in most cases and in most of the situations, the Glorious Qur'an is the basis of the power behind Islamic magic and it allows the use of charms in averting evil, provided only names of Allah and words and phrases from the Qur'an and other invocatory books are used.

${ }^{21}$ The few cases involving litigation sited are extreme exceptions to the general rule because distribution of estates in Ilorin are not usually done through court litigation

${ }^{22}$ Right of appeal is a constitutional right of litigants that should be utilized properly and not wrongly by their counsel. Hence, counsel should advise their clients properly in the best interest of the clients.

${ }^{23}$ Unreported Suit No. UACI/CVF/9/2002 delivered on 0804-2005.

${ }^{24}$ State High Court in its appellate jurisdiction. See Unreported High Court (Appeal) Suit No. KWS/8A/06 where one Mrs Jibola Adebayo for herself and other appellants applied to withdraw the appeal and the appeal was thereafter struck out on 23rd January, 2007.

${ }^{25}$ Mallam Akanni Akibu \& 5 Others v. Mrs Iyabo Imam (KWS/SCA/CV/AP/IL/05/2005), see also Sharia Court of Appeal Annual Report (Kwara State, 2006), 68.

${ }^{26}$ Mrs. Iyabo Imam v. Mallam Akanni Akibu \& 5 Others (KWS/SCA/CV/M/IL/15/2005), see also Sharia Court of Appeal Annual Report (Kwara State, 2006) 55 at 67.

${ }^{27}$ Mallam Akanni Akibu, op. cit., 68 at 72.

${ }^{28}$ Mallam Akanni Akibu \& 5 Others v. Mrs Iyabo Imam, unreported Suit No. KWS/8A/06.

${ }^{29}$ The withdrawal was probably as a result of Counsel realizing the fact that there is a fundamental defect in the notice and grounds of appeal and the relief(s) sought from the Court transferred from Sharia Court of Appeal to High Court are not tenable before the State High Court in its appellate jurisdiction but only tenable in the Sharia Court of Appeal. The State High Court in its appellate jurisdiction cannot distribute estate in accordance with Islamic Law.

${ }^{30}$ Unreported Suit No. CVFM/3/2007 delivered on 09-052007. Mrs. Tinuke Akibu is daughter of Mallam Akanni Akibu. Akanni Akibu died before the matters were dis- posed off, hence his daughter stepped in and she and her other siblings received Late Akanni Akibu's share in the estate.

${ }^{31}$ Op. cit.

${ }^{32}$ Opobiyi v. Muniru (2004) 5 F. R. 43.

${ }^{33}$ Certified True Copy of Ruling of Court of Appeal, Ilorin Division, delivered by J. C. A. Muntaka Coomassie, (as he was then) [Monday, 6th February, 2006], 5.

34 Appellants' counsel filed Appellants' Brief of Argument, a necessary step in hearing of the appeal.

${ }^{35}$ Within the class referred to as the courts are the Area Courts which include the Upper Area Court (in both original and appellate functions), the Shari'ah Court of Appeal, the Court of Appeal and the Supreme Court in their appellate jurisdictions.

${ }^{36}$ The other two classes are the Ulamas, i. e, Alfas / Afas (Local Mallams), and Kadis of the Kwara State Sharia Court of Appeal in their quasi-judicial functions.

37 Shari'ah Court of Appeal, Court of Appeal and the Supreme Court.

${ }^{38}$ Section 277 (1), Constitution of the Federal Republic of Nigeria 1999. See also Section 242 (1), Constitution of the Federal Republic of Nigeria, 1979 in respect of Sharia Court of Appeal.

${ }^{39}$ See Section 10 (1), Sharia Court of Appeal Law, Cap. S4, Revised Edition (Laws of Kwara State of Nigeria) Law, 2006 which is in pari material with Section 10 (1), Cap. 122, Laws of Northern Nigeria, 1963, in respect of Sharia Court of Appeal and Sections 244 and 233 of the Constitution of the Federal Republic of Nigeria, 1999, in respect of Appeal from Sharia Court of Apeal to Court of Appeal and from Court of Appeal to the Supreme Court respectively.

${ }^{40}$ Op. cit., a case conducted by the researcher, delivered on 9th May, 2007.

${ }^{41}$ Op. cit., suit handled by the Law Firm of the researcher, delivered on 8th April, 2005.

${ }^{42}$ Sections 3 (1), 70 (1) \& (2) Native Courts Law, Cap. 78, Laws of Northern Nigeria, 1963.

${ }^{43}$ Section 3 (1) Area Courts Law, Cap. A9 Revised Edition (Laws of Kwara State of Nigeria) Law, 2006 which is in pari material with Section 3 (1) Area Courts Law, Cap. 9, Annual Vols. of the Laws of Kwara State of Nigeria, 1967 and 1968. See also Section 3(1), The Area Courts Edict, Edict No. 2, Annual Vols. of the Laws of Kwara State of Nigeria, 1967.

${ }^{44}$ Section 2, Native Courts Law, Cap, 78, Laws of Northern Nigeria, 1963; See also Section 4 (1) (a) (b) and (2), Area Courts Law, Cap. 9, Laws of Kwara State, 1968.

${ }^{45}$ Section 61 (1) \& 2 (a) \& (b) Native Courts Law, Cap. 78, Laws of Northern Nigeria 1963.

${ }^{46}$ Majority of them attended Makarantar Alo, Makarantar Ilimi and or Kano Law School.

${ }^{47}$ Section 4A (2), Area Courts Law, Cap A9, Revised Edition (Laws of Kwara State of Nigeria) Law, 2006. 
${ }^{48}$ Section 4A (1) (a) \& (b), Area Courts Law, Cap A9, Revised Edition (Laws of Kwara State of Nigeria) Law, 2006.

${ }^{49}$ Section 2 (1) Legal Practitioners Act 1962, now Legal Practitioners Act, Cap. 207, Laws of the Federation, 1990; See also Section 24, Legal Practitioners Act which defines a "Legal Practitioner" as a "person entitled in accordance with the Legal Practitioners Act to practice as a barrister and solicitor either generally or for the purpose of any particular office or proceeding".

${ }^{50}$ Attitude of Court staff, attitude of lawyers (already discussed above), attitude of Court not sitting at times, poor condition of service and corrupt tendencies.

${ }^{51}$ (2006) Annual Report of Kwara State Sharia Court of Appeal, Ilorin, 262

${ }^{52}$ Ibid, p. 269, see also Funmilayo Ajoke v. Taiye Ile Balogun (Suit No. KWS /SCA/CV/AP/IL/13/2001) case listed as No. 32 (disposed of after $3 \frac{1 / 2}{2}$ years, in 10 adjournments) in (2001) Annual Reports of Kwara State Sharia Court of Appeal, Ilorin, at xx.

${ }^{53}$ Asemota, Solomon "Unhealthy State of the Nation", Opinion, The Guardian, Thursday, (April 14, 2011): 79.

${ }^{54}$ U. Lawani, "Salami vs. Katsina-Alu", Opinion, The Guardian, (Thursday, February 15, 2011), 67.

${ }_{55}$ Asemota, op. cit.

${ }^{56}$ Asemota, op. cit.

${ }^{57}$ MCIA/225/2011

${ }^{58}$ These were the former four semi-autonomous hamlets of Gaa Fulani, Gambari, Oke-Suna and Idiape which confederally formed Ilorin at that time. See L.A.K. Jimoh, (ILORIN: The Journey So Far, Ilorin: Atoto Press Ltd, 1994), 51.

${ }^{59}$ Solagberu, an itinerant Muslim preacher was the leader and head of Oke-Suna which was predominantly a Muslim settlement and around him "flocked Mohammedans from Gbanda, Kobayi, Igboho, Kuwo and Kobe. All in his quarters being Moslems" shows that Ilorin before the arrival of Sheikh Alimi had Islamic scholars; See Jimoh, Ibid., 52. See also A.S. Hassan, A.J. and Ibrahim, "Ilorin Emirate: Its People and Politics" in Jimoh, S. A. (Ed.), (n. d.), (ILORIN: Centre of Learning, Ilorin: Jimson Publishers), 8.

${ }^{60}$ After the arrival of Sheikh Alimi, the number of Islamic scholars in Ilorin continued to blossom because from far and near, all over Yorubaland and beyond, Muslims flocked to Sheikh Alimi and Ilorin became "a sort of Islamic lighthouse to which the Yoruba Muslim turned for study and guidance". See Jimoh, 53.

${ }^{61} \mathrm{He}$ is no doubt an Islamic scholar of repute, he is of "high intellect and wide experience in the different fieldof Islamic Science such as Jurisprudence and Quranic exegesis of Jalalayn especially of the second half of the Qur'an which no one else had in Ilorin". See A. S. Hassan and A. J., Ibrahim, op. cit., 8, see also Jimoh, op. cit., 50. See further S. Johnson, The History of the Yorubas (Lowe \& Brydone Printers Ltd, 1921), 194.
${ }^{62}$ A random sampling of very few of them are: Shaykh Abubakar Bube, Shaykh Abubakar Salekoto, Shaykh Sa'du Kokewukobere, Shaykh Muhammad Jami' Tajul-Adab, Shaykh Muhammad Kamaldeen al-Adaby, Shaykh Adam Abdullahi al- Ilori and a lot of them too numerous to mention here. For a more detail list, see Z. I. Oseni, "Arabic and Islamic Scholarship in Ilorin" in S.A. Jimoh, (Ed.), (ILORIN: Centre of Learning, Ilorin: Jimson Publishers, n. d.), pp. 56-65.

${ }^{63}$ Among those in this category are: Shaykh Abdul-Raheem Ameen Abata, Hon. Justice Abdul-Kadir Orire (retired Grand Kadi, Kwara State), Hon. Justice Mutallib Ahmad Ambali (retired Grand Kadi, Kwara State), Shaykh Muhammad Bashir Salih, Shaykh Safiyullah Kamaldeen, Dr. Isa Alabi, Dr. Hamzah Ishola Abdur-Raheem, Prof. Badamasi Olanrewaju Yusuf, Shaykh Waliyu Ali-Kamal, Prof. Abdul Baqi Agaka and a host of others too numerous to mention. For a more detailed list see Oseni, Ibid.

${ }^{64}$ Interview with Hon. Justice Ambali, op.cit.; see also M. A. Ambali,. Islamic Law Principles of Reconciliation and Arbitration, ( Ijebu-Ode: Shebiotimo Publications, 1431 A. H./2010 C. E.), 35.

${ }^{65}$ For instance, Alhaji Abdus-Salam Oniwiridi Pakata, Shaykh Ahmad Rufa'i b. Abubakar Inda-Salati amongst others are acclaimed and known for specialization in Sufism of the Tijjaniyyah and Kadiriyyah sects respectively in Ilorin.

${ }^{66}$ Shaykh Abdul-Raheem Ameen Abata is known and acclaimed scholar with specialization in general Arabi andIslamic Scholarship and Da'wah. He is the Chief Missioner of Ansarul-Islam Society of Nigeria ("Oni wasi agbaye").

${ }^{67}$ Ambali, op. cit, 35.

${ }^{68}$ This is often not the fault of the Alfas because the layman or the ordinary man sees anybody in the position of an $\mathrm{Al}$ $f a$ to be a person knowledgeable and versed in the law, skill and art of estate distribution.

${ }^{69}$ Op. cit., carried out on Saturday, 18th May, 2008.

${ }^{70}$ The researcher wishes to make the identity of the heirs and the estate anonymous in accordance with undertaking with one of the heirs on 26th July, 2008 not to make the particulars and details public.

${ }^{71}$ Probably due to the anticipated honorarium they will get from such exercise.

${ }^{72}$ To avoid disharmony among the heirs and to allow tempers to cool down in order to invite another set of Mallams to do the distribution.

${ }^{73}$ Equivalent of Junior Secondary School (JSS) while Sanawi is the Senior Secondary School (SSS) equivalent.

${ }^{74} \mathrm{H}$. Abdulsalam, "The Practice of Islamic Law of Inheritance: Correction of Some Anomalies", NATAIS, Vol. 6, No. 2, (September, 2002): 42.

${ }^{75}$ M. B. Y. M. Q. Imam Abu Abdullahi, Sunan Ibn-i-Majah (Vol. IV), (English Version by Muhammad Tufai Ansari), Book of Fara'id, (Rules of Inheritance) Hadith No. 2717, (New Delhi: Nusrat Ali Nasri for Kitab Bhavan, 2005), 108. 
${ }^{76}$ Experts as used here is not limited to Islamic Law experts alone but includes other professionals such as estate valuers, automobile engineers, motor mechanics, stockbrokers and a host of other professionals.

77 A. A. Oba, "The Sharia Court of Appeal: Accounting to the Public in Kwara State", The Jurist, An Annual Publication of Law Students' Society, Vol. 10 (Ilorin:University of Ilorin, Ilorin, 2005), 165.

${ }^{78}$ Abdulsalam, op. cit.

${ }^{79}$ Abdulsalam, op. cit.

${ }^{80}$ The Nation Newspaper, September 13th, (2007): 8.

${ }^{81}$ From 1998 to 2011.

${ }^{82}$ This is what Ahaji Murtala Abdul-Ganiyu described as gender oppression in my interview with him on the 1st day of September, 2010.

${ }^{83}$ Mr. Musa Abdullahi v. G. B. Amao, unreported Suit No. MCI/1017/2001 concluded on 28-03-2002, Mr. Musa Abdullahi v. Mr. P. A. Operemu, unreported Suit No. MCI/138/2002 and Mr. Musa Abdullahi v. Mr. A. Ibrahim, unreported Suit No. MCI/1016/2001 concluded on 28-032002.

${ }^{84}$ A modern 3-bedroom flat with electricity and pipe borne water which was hitherto let out for a paltry sum of $\$ 200.00$ per month, instantly attracted the sum of $\$ 2,000.00$ per month with a year rent paid in advance by the same tenants who were in default of payment of two hundred Naira per month as at 2001/2002.

${ }^{85}$ Annual Report, (Ilorin, Kwara State Sharia Court of Appeal, 2006), 338, especially at 366-403.

${ }^{86}$ Alhaji Adebayo Busari Alaya, op. cit., 366-403.

${ }^{87}$ The Yoruba custom is generally silent on the time frame within which to effect distribution of estate of a deceased. However, it is a common practice among the Yorubas, especially the Ijebu, to distribute the estate after the final funeral ceremony called $i w o l e f u$. The exact date of $i w o l e f u$ is usually agreed upon by the family and the economic situation of the relatives play significant role in determining this date. Where the families of the deceased are economically strong, they fix it at forty days and in other cases, a year later to enable each member prepare adequately. See Y. Sodiq, "An Analysis of Yoruba and Islamic Laws of Inheritance" The Muslim World, Vol. 86, Issue 3-4, (April, 2007): 322.

${ }^{88}$ When Aus bin Malik (R.A.) passed away, he left behind a wife, two young daughters and an infant son. The cousins of the deceased took away whatever was left behind. The Widow of Aus bin Malik (R.A.) brought her complaint to Rasulullah $(S A W)$ and informed him that she and her children were totally deprived of their inheritance. Rasulullah (P.B.U.H.) asked her to be patient until Allah Ta'ala revealed something in this regard and not long after this, a similar incident occurred with the Widow of Sa'ad bin Rabi' (R. A.). See Qur'an 4:7 where Allah provides that: "And for the males is a share of what has been left behind by the parents and relatives and for the females is a share of what has been left by the parents and relatives".
${ }^{89}$ Interview with Hon. Justice M. A. Ambali, (rtd), op. cit.

${ }^{90}$ So many factors account for the snail like pace of administration of justice in Ilorin. These include lawyers attitude, attitude of court staff and the court not sitting at times and too many cases in a particular court due to non conclusion as at when due.

${ }^{91}$ See Alhaji Alabi Opobiyi v. Alhaja Senabu Abebi Masingba (1982) C. A. (Pt. 1), 206; Ahaji Saka Opobiyi v. Layiwola Muniru in Unreported Suit No. CA/IL/SH/3/99 delivered on 11th day of July, 2002 and Alhaji Saka Opobiyi v. Muniru (2011) 12 MJSC (Pt. II).

\section{Selected Bibliography}

Abdul, M.O.A. The Selected Traditions of AL-NAWAWI (The Forty Traditions of AL-NAWAWI Arabic Text, Transliteration, Translation \& Commentary) (Book 4). Lagos: Islamic Publications Bureau, 1974.

Abdulsalam, H. "The Practice of Islamic Law of Inheritance: Correction of Some Anomalies." NATAIS, Vol. 6, No. 2, (September, 2002).

also A.S. Hassan, A.J. and Ibrahim, "Ilorin Emirate: Its People and Politics" in Jimoh, S. A. (Ed.), (n. d.), ILORIN: Centre of Learning, Ilorin: Jimson Publishers.

Ambali,. M. A. Islamic Law Principles of Reconciliation and Arbitration. Ijebu-Ode: Shebiotimo Publications, 1431 A. H./2010 C. E. Imam Abu Abdullahi, Sunan Ibn -i-Majah (Vol. IV), (English Version by Muhammad Tufai Ansari), Book of Fara'id, (Rules of Inheritance), New Delhi: Nusrat Ali Nasri for Kitab Bhavan, 2005), 108.

Johnson, S. The History of the Yorubas. Lowe \& Brydone Printers Ltd, 1921.

Kaniki, M. H. Y. "Religious Conflict and Cultural Accommodation: The Impact of Islam on Some Aspects of African Societies." UTAFITI Journal of the Arts and Social Sciences, A Journal of the Faculty of Arts and Social Sciences, University of Dar es Salaam, Vol. 1, no. 1, (1976). L.A.K. Jimoh, ILORIN: The Journey So Far. Ilorin: Atoto Press Ltd, 1994.

Oseni, Z. I. "Arabic and Islamic Scholarship in Ilorin" in Jimoh, S. A. (Ed.), ILORIN: Centre of Learning, Ilorin: Jimson Publishers, n. d.

Sodiq, Y. "An Analysis of Yoruba and Islamic Laws of Inheritance" The Muslim World, Vol. 86, Issue 3-4, (April, 2007). 